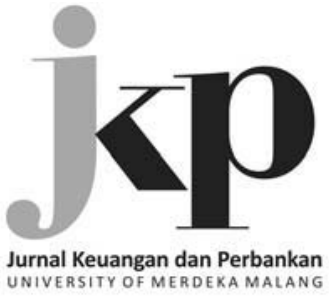

Article history:

Received: 2017-11-04

Revised: 2018-02-04

Accepted: 2018-04-05

\section{Eristy Minda Utami}

Department of Management, Faculty of Business and Management University of Widyatama Jl. Cikutra No.204A Bandung, 40125, Indonesia

Corresponding Author:

Eristy Minda Utami:

Tel. /Fax. +62 821-2160-7599

E-mail: eristy.minda@widyatama.ac.id

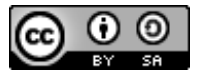

This is an open access article under the CC-BY-SA license

Eristy Minda Utami (Indonesia)

\title{
The Intellectual Capital Components on Firm Value: Evidence from LQ-45 Index Companies
}

\begin{abstract}
The purpose of this research is to analyze the influence of Intellectual Capital components on the firm value. Data used in this research is secondary data with sampling method is purposive sampling. The population of this study is companies listed in LQ-45 period 2012-2015, then selected to be sampled in these study as many as 96 companies are observed. The analytical tool to test of hypothesis is multiple regression analysis. The result of Value Added Capital Employed (VACA) affects the firm value. This means that information about the efficient use of capital employed is captured by the market (investor) so as to affect the firm value, Value Added Human Capital (VAHU) affect the firm value, because the company has the best employees with a ratio perpendicular to the cost incurred by the company, get a lot of value added on them. Structural Capital Value Added (STVA) does not affect the firm value. This shows that the company's operational systems, organizational culture, management philosophy and all forms of intellectual property owned by the company are inefficient and economical in creating added value for the company.
\end{abstract}

Keywords: Firm Value; Intellectual Capital; Structural Capital Value Added; Value Added Capital Employed; Value Added Human Capital

JEL Classification: G32; J24; O34

Citation: Utami, E. M. (2018). The intellectual capital components on firm value: Evidence from LQ-45 Index Companies. Jurnal Keuangan dan Perbankan, 22(2), 291-300. https://doi.org/10.26905/jkdp.v22i2.1648

\section{Abstrak}

Tujuan penelitian ini adalah untuk menganalisis pengaruh komponen-komponen Intellectual Capital terhadap nilai perusahaan. Data yang digunakan dalam penelitian ini adalah data sekunder dengan metode pengambilan sampel yaitu metode purposive sampling. Populasi penelitian ini adalah perusahaan-perusahaan yang terdaftar pada LQ-45 periode 2012-2015, yang kemudian terpilih sampel dalam penelitian ini sebanyak 96 perusahaan yang diobservasi. Alat analisis untuk menguji hipotesis yaitu analisis regresi berganda. Hasil penelitian Value Added Capital Employed (VACA) berpengaruh terhadap nilai perusahaan. Ini berarti informasi mengenai efisiensi penggunaan capital employed ditangkap oleh pasar (investor) sehingga berpengaruh terhadap nilai perusahaan. Value Added Human Capital (VAHU) berpengaruh terhadap nilai perusahaan, dikarenakan perusahaan mendapatkan banyak value added dari karyawan terbaiknya. Structural Capital Value Added (STVA) tidak berpengaruh terhadap nilai perusahaan. Ini menunjukan bahwa sistem operasional perusahaan, budaya organisasi, filosofi manajemen dan semua bentuk intellectual property yang dimiliki perusahaan tidak efisien dan ekonomis dalam menciptakan nilai tambah bagi perusahaan.

Kata Kunci: Nilai Perusahaan; Intellectual Capital; Structural Capital Value Added; Value Added Capital Employed; Value Added Human Capital 
Increasingly tough business competition is currently affecting various indexes that contain preferred stock. One of them is the LQ-45 index. As happened on the performance of an LQ-45 index of 45 January 2017 where the LQ-45 index weakened by 0.34 percent to the position of 889.09 . This weakness occurs in the middle of the world stock market is also in the weakening trend (finance.detik.com).

Getting a high return on investment is the goal of investors investing. Increasing profits and maximum return will affect the value of a company. The higher the profit the company generates, the higher the firm value. The firm value (Dewi, Handayani, \& Nuzula, 2014) if not go public is the value that occurs when the company is sold. The firm value is reflected in the value of its stock market if the company is going public. Therefore, the main purpose of a go public company is to increase the prosperity of the owner or shareholders through increasing the firm value (Hermuningsih, 2012). The firm value serves as a measure of the success of the company's management in the prospect of future operations to realize trust for its shareholders (Pratama \& Wiksuana, 2016). The firm value is very important because it reflects the performance of the company that can affect investors' perceptions of the company (Nopiyanti \& Darmayanti, 2016). If the firm value is good, then the company will be viewed favorably by potential investors, and vice versa. The purpose of increasing the firm value should be the basis for decision making to be taken by the management company. Proper and correct decisionmaking will increase the firm value and ultimately will affect the prosperity of the company.

Value added for the company one of which can be obtained from Intellectual Capital. Intellectual Capital disclosure becomes an important part of improving the firm value and financial performance. Companies that can utilize their intellectual capital disclosure efficiently will increase their firm value (Werastuti, 2014). Suhardjanto \& Wardhani (2010) states that the benefits that can be obtained from the intellectual capital are that companies can reduce information asymmetry and can help reduce the company's capital costs. Research conducted by Yunita (2012) and Simamarta \& Subowo (2016) showed that intellectual capital could increase the firm value. This indicates that the market (investor) provides a higher price to book value to companies with larger intellectual capital. The findings of this study prove that the market rewards in a company are based more on the company's intellectual resources.

Lin et al. (2018) found the results of empirical studies that the performance of the construction industry business listed in the Taiwan market relies heavily on intellectual capital. As a result, managers of related construction companies should place more emphasis on the accumulation of intellectual assets to improve their business performance. Furthermore, the empirical results also show that the traditionally conceived 'capital and labor-intensive' construction industry is highly intellectually capitalized.

Intellectual Capital can be defined as the sum of what is produced by the three main elements of the organization (human capital, structural capital, and customer capital/ capital employed) related to knowledge and technology that can give more value to the company in the form of organizational competitive advantage (Fajriani, 2017). Now the company recognizes the importance of abstract intellectual capital to become the main driving force in business development. Intellectual capital consisting of capital employed, human capital, and structural capital is part of the intangible assets now called an important factor in increasing the firm value.

To create value added, the right size of Intellectual Capital is needed (Ulum, 2013) physical capital (VACA-value added capital employed), human capital (VAHU-value-added human capital), and structural capital (STVA-structural capital value added). 


\section{The Intellectual Capital Components on Firm Value: Evidence from LQ-45 Index Companies \\ Eristy Minda Utami}

According to Ulum (2013), VACA is an added value indicator created by a physical capital unit. Research by Wahyuni, Suratno, \& Anwar (2017) show VACA affects the firm value. This indicates that the market (potential investors) gives greater value to companies that have physical capital. However, Nurani, Zulbahridar, \& Azhari (2014) show physical capital (VACA) has no significant effect on firm value. This means that physical capital cannot generate added value for the company to increase the market firm value.

The investment in human resources has a major impact on productivity gains (Simarmata \& Subowo, 2016). VAHU shows how much value added is formed by each currency unit (rupiah) spent to pay for existing employees and work in the company. Research by Fajriani (2017) reveals that VAHU affects the firm value. The higher the burden of employees issued by the company will increase the value added (value added) which will impact on the increase of the firm value). In contrast to the study Maditinos et al. (2011) and Susanti (2016), which showed insignificant VAMU results. In this study indicates that the cost incurred by the company for employees is not very efficient to generate added value for the company. Li \& Zhao (2018) identify causality and find no significant relationship between human capital and firm value, but findings are robust to different firms with different property rights, of capital-intensive firms, in which human capital has a significant influence on firm value.

STVA is a structural capital contribution needed to generate 1 rupiah of value added. The higher STVA will provide a higher price to book value ratio as well. Then it can be concluded that the greater contribution of structural capital in the creation of added value for the company will increase the market valuation of the company's value (Fajriani, 2017). The results of Dewi \& Isynuwardhana (2014) show that STVA does not affect firm value. This indicates that the company's structural capital is believed to have not been able to increase the firm value.
Intellectual Capital components will show how the company's resources have been efficiently utilized by the company to provide value-added that can increase the firm value. Sumedrea (2013) analyzes the structure of the intellectual capital and its influence on the economic performance based on the VAIC model. The results are obtained by applying certain regression models and suggest that, in crisis time, the development of companies is influenced by the human and the structural capital, while profitability is additionally linked to the financial capital through the value-added intellectual capital coefficient. Based on the description of the background that has been proposed, this study aims to examine the influence of Intellectual Capital components, namely physical capital (VACA), human capital (VAHU), and structural capital (STVA) to the firm value.

\section{HYPOTHESES DEVELOPMENT}

VACA is an indicator for VA created by a unit of physical capital. Fajarini \& Firmansyah (2017) explains that physical capital efficiency is financial capital, which is all tangible capital such as cash, marketable securities, receivable accounts, inventories, land, buildings, machinery, equipment, furniture, fixtures, and vehicles owned by the company. Ulum (2013) assumes that if 1 unit of CE (Capital Employed) produces a larger return than any other company, then that means the company is better at utilizing its CE. Thus, better utilization of intellectual capital is part of the company's intellectual capital.

Nurani, Zulbahridar, \& Azhari (2014) state that to create value added to the company, the need for intellectual is physical capital as the main parameter. Research by Entika (2012) and Wahyuni, Suratno, \& Anwar (2017) has proved that VACA affects the firm value. Fajarini \& Firmansyah (2012) study showed that VACA positively influences firm value. When the company can manage the $\mathrm{CE}$ well than any other company, it is believed that the company's financial performance will increase, fol- 
lowed by an increase in the firm value as reflected in the stock price paid by investors. Based on his research provides evidence that the higher the ratio of physical capital, the higher the efficiency of its use in the process of creating corporate value. Thus, the high efficiency in the use and the process of value creation, the market firm value can increase because Intellectual is the physical capital owned by the company well managed.

$\mathrm{H}_{1}$ : capital employed value added (VACA) affects firm value

VACA is an indicator for VA created by a unit of physical capital. In Fajarini \& Firmansyah (2017) physical capital efficiency is financial capital, which is all tangible capital such as cash, marketable securities, receivable accounts, inventories, land, buildings, machinery, equipment, furniture, fixtures, and vehicles owned by the company. Ulum (2013) assumes that if 1 unit of CE (capital employed) produces a larger return than any other company, then that means the company is better at utilizing its CE. Thus, better utilization of intellectual capital is part of the company's intellectual capital.

The research of Hamidah, Ahmad, \& Aulia (2015), Fajriani (2017), and Wahyuni, Suratno, \& Anwar (2017) managed to prove that VAHU affects the firm value. Companies that have budgeted high staff burdens will expect to get a high VA from their employees such as through employee productivity, which will later be believed to increase the firm value. Human capital can increase if the company can utilize and develop the knowledge, competence, and skills of its employees efficiently. Therefore, human capital is a key resource that can create a competitive advantage so that companies can compete and survive in a dynamic business environment. By having skilled and skilled employees, it can increase the firm value.

$\mathrm{H}_{2}$ : value-added human capital (VAHU) affects firm value
Structural Capital Coefficient (STVA), which shows the contribution of structural capital (SC) in value creation. Structural capital reflects the company's capabilities derived from the system, process, structure, culture, strategy, policy, and ability of the company to innovate (Fajarini \& Firmansyah, 2017). In the public model, SC is the VA minus HC. If the contribution in HC value creation is lacking, then the greater the contribution of SC (Ulum, 2013).

Furthermore, Nurani, Zulbahridar, \& Azhari (2014) mention that structural capital includes all non-human storehouses of knowledge within the organization. These include databases, organizational charts, process manuals, strategies, routines, and everything that makes the value of a company greater than its material value. If an organization can codify the company's knowledge and develop structural capital such as creating a good routine, then a competitive advantage will be achieved that will relatively result in higher business performance thereby increasing the market firm value. This has been proved by research Chen, Cheng, \& Hwang (2005) and Entika (2012) that successfully proves the influence of STVA on firm value. Fajarini \& Firmansyah (2012) stated that STVA is the most significant component in forming intellectual capital and has been able to create value added. $\begin{array}{ll}\mathrm{H}_{3} \text { : } & \text { structural capital coefficient (STVA) affects } \\ & \text { firm value }\end{array}$

\section{METHODS}

The data analyses used in this research include classical assumption test, multiple linear regression analysis, F test, and t-test. Observations were made on the Blue Chips stocks of the LQ-45 index which in this index consists of various companies from various industries. This research uses purposive sampling method. Purposive sampling is a sample taken as the name implies, that is with a particular purpose and purpose (Nuryaman \& Christina, 2015). 
Someone or something is taken as because the researcher assumes that a person or something has information or characteristics appropriate to the needs of his research. Determination of sample criteria is needed to avoid the occurrence of errors in research which will then affect the value of the analysis. Based on the results of the company's financial statements of the period 2012-2015 which is published on the Indonesian Capital Market Directory and Jakarta Stock Exchange yearly statistics there are 92 companies that can be used as research samples.

Table 1. Sampling Criteria

\begin{tabular}{lc}
\hline \multicolumn{1}{c}{ Criteria } & Total \\
\hline Companies listed in LQ 45 period & 45 \\
2012-2015 & \\
$\begin{array}{l}\text { Inconsistent companies entered into LQ 45 } \\
\text { during the period (February 2012-January }\end{array}$ & \\
2016). & \\
Total Sampling & 24 \\
Total Observation (24 x 4 year) & $\mathbf{9 6}$ \\
\hline
\end{tabular}

Operationalization of variables in this study describes the variables used. Consisting of 3 independent variables are VACA $\left(X_{1}\right)$, VAHU $\left(X_{2}\right)$, SCVA $\left(\mathrm{X}_{3}\right)$, and the dependent variable is a firm value $(\mathrm{Y})$.

Pre regression test is done first and then proceed with hypothesis testing. This test aims to test the validity and validity of regression model estimation results. Some classic assumptions that must be met are normality test, multicollinearity test, heteroscedasticity test and autocorrelation test.

The method of analysis of this study is using multiple linear regressions. According to Riduwan (2012), "Multiple regression tests is a prediction analysis of the value of the effect of two independent variables or more against one particular variable". The analyzer is using SPSS version 20. Analysis of correlation coefficient aims to measure the strength and direction of the relationship between independent variables with independent variables, then performed multiple correlation analysis (mul-

Table 2. Variable Operationalization

\begin{tabular}{|c|c|c|c|c|}
\hline Variable & Sub Variable & Concept Variable & Indicator & Scale \\
\hline \multirow[t]{2}{*}{$\begin{array}{l}\text { The firm } \\
\text { value }\end{array}$} & $\begin{array}{l}\text { PBV } \\
(Y)\end{array}$ & $\begin{array}{l}\text { Price Book Value is a ratio that } \\
\text { illustrates how much the market } \\
\text { appreciates the value of a } \\
\text { company's stock book. }\end{array}$ & PBV $=\frac{\text { Market Price/Share }}{\text { Book Value/Share }}$ & \\
\hline & $\begin{array}{l}\text { Value Added } \\
\text { Capital } \\
\text { Employed } \\
\text { (VACA) (X1) }\end{array}$ & $\begin{array}{l}\text { VACA is an indicator for VA } \\
\text { created by a unit of physical } \\
\text { capital. This ratio shows the } \\
\text { contribution made by each unit of } \\
\text { CE to the value of the } \\
\text { organization. }\end{array}$ & VACA $=\frac{\text { Value Added }}{\text { Capital Employed }}$ & Ratio \\
\hline \multirow[t]{2}{*}{$\begin{array}{l}\text { Intellectual } \\
\text { Capital }\end{array}$} & $\begin{array}{l}\text { Value Added } \\
\text { Human Capital } \\
\text { (VAHU) (X2) }\end{array}$ & $\begin{array}{l}\text { VAHU shows how much VA can } \\
\text { be generated with funds spent on } \\
\text { labor. }\end{array}$ & VACA $=\frac{\text { Value Added }}{\text { Human Capital }}$ & Ratio \\
\hline & $\begin{array}{l}\text { Structural } \\
\text { Capital Value } \\
\text { Added (STVA) } \\
\text { (X3) }\end{array}$ & $\begin{array}{l}\text { STVA measures the SC required } \\
\text { to generate } 1 \mathrm{~K} \text { of } \mathrm{VA} \text { and is an } \\
\text { indication of how SC's success is } \\
\text { in value creation. }\end{array}$ & STVA $=\frac{\text { Structural Capital }}{\text { Value Added }}$ & \\
\hline
\end{tabular}


tiple correlations). The analysis of coefficient of determination $\left(R^{2}\right)$ according to Ghozali (2013) is done to measure how far the ability of the model in explaining the independent variables.

Partial hypothesis testing (t-test) is done to show the influence of independent variables individually to dependent variable constantly. It is using the significance level of $(\alpha) 5$ percent (0.05). Acceptance or rejection criteria will be based on the probability value of significance. If $t$ arithmetic $>$ of $t$ table or probability is smaller than the level of significance $($ Sig < 0.05$)$ then the independent variables affect the dependent variable and if $t$ arithmetic < of $t$ table or probability greater than the level of significance (Sig > 0.05) then the independent variable has no effect on the dependent variable (Ghozali, 2013).

\section{RESULTS}

\section{The Results of Testing Classical Assumptions}

Classical assumption test, according to (Ghozali, 2013), the normality test is to test whether the regression model, the independent variable, and its dependent variable have normal or abnormal data distribution. The classical assumption test consists of normality test, heteroscedasticity test, multicollinearity test, and autocorrelation test.

The results of normality test using KolmogorovSmirnov test obtained a significance value of 0.485 . Because the value of significance in the KolmogorovSmirnov test is still greater than the error rate of 5 percent (0.05), it is concluded that the regression model is normally distributed.

Then multicollinearity test results show no strong correlation between independent variables; this is indicated by the value of variance inflation factor (VIF) the third independent variable is still smaller than 10 .
Table 3. Results Multicollinearity Test

\begin{tabular}{lcc}
\hline \multicolumn{1}{c}{ Variable } & VIF & Tolerance \\
\hline VACA & 2.194 & 0.456 \\
VAHU & 2.548 & 0.392 \\
STVA & 1.247 & 0.802 \\
\hline
\end{tabular}

The autocorrelation test using Durbin-Watson values falls in the area of positive autocorrelation, but as Gujarati \& Porter (2009) states “The existence of autocorrelation in the regression model, estimation results are still unbiased and consistent, but less efficient". So although there are symptoms of autocorrelation in the model will not interfere with test results, it will only reduce the reliability of the predicted results.

Finally, the result of heteroscedasticity test using scatter plot showed no pattern on the scatter plot chart between the predicted values of the bound variable (ZPRED) with residual value (SDRESID), so it indicated no heteroscedasticity in the regression model used.

\section{The Correlation Analysis, Coefficient of Determination, and Hypotheses Test}

The analysis of coefficient of determination $\left(R^{2}\right)$ according to Ghozali (2013) is done to measure how far the ability of the model to explain the independent variables. The coefficient of determination is between zero and one. The value of the coefficient of determination is small indicates that the ability of independent variables in explaining the dependent variable is very limited. If the value of $R^{2}$ is 0 , then shows the model does not explain the influence of independent variables on the dependent variable. This model will be said to be good if the value of $R^{2}$ is closer to 1 . The coefficient value of determination is $0 \leq R^{2} \leq 1$. 
Table 4. The result of Coefficient Determination

\begin{tabular}{ccccc}
\hline Model & R & R Square & Adjusted R Square & Durbin-Watson \\
\hline 1 & $0.669^{a}$ & 0.448 & 0.430 & 0.450 \\
\hline
\end{tabular}

In Table 4 shows that the results of the coefficient of determination coefficient of 0.448 or 44.8 percent. This shows that the variable of VACA, VAHU, and STVA give 44.80 percent influence to the firm value (PBV). While as many as 100 percent - 44.80 percent $=55.20$ percent explained by other factors not described in this study.

Table 5. Regression Analysis Results

\begin{tabular}{lrrr}
\hline \multicolumn{1}{c}{ Model } & B & t & Sig. \\
\hline (Constant) & 0.321 & 0.251 & 0.803 \\
VACA & 9.618 & 8.556 & 0.000 \\
VAHU & -0.235 & -5.658 & 0.000 \\
STVA & 0.029 & 0.690 & 0.802 \\
\hline
\end{tabular}

Dependent Variable: PBV

Based on Table 5, the equation of the above variables can be interpreted each variable as follows: (1) the constant number of 0.321 in the equation above shows that if the firm does not have VACA, VAHU, and STVA, then PBV will still take place at the level of 0.321. The independent variable regression coefficient shows the direction and magnitude of the relationship of variables VACA, VAHU, and STVA, to PBV; (2) VACA has a coefficient value of 9.618. This illustrates that when Capital Employed increases 1 percent, it will increase PBV by 9.618; (3) VAHU has a coefficient value of -0.235 . This illustrates that when Human Capital increases 1 percent will decrease PBV by 0.235 ; and (4) STVA has a coefficient value of 0.029 . This illustrates that when Structure Capital increases 1 percent will increase PBV by 0.029 .

Table 6. F Test Results

\begin{tabular}{lccc}
\hline \multicolumn{1}{c}{ Model } & Sum of Squares & F & Significance \\
\hline Regression & 3581.528 & 44.855 & 0.000 \\
Residual & 4418.970 & & \\
Total & 8000.498 & & \\
\hline
\end{tabular}

Based on the results in Table 6, obtained significance value of regression model simultaneously of 0.0000 , this value is smaller than significance level 0.05 or $0.0000<0.05$. It can be concluded that VACA, VAHU, and STVA variables affect PBV.

Based on Table 7, we will show partial test results from intellectual capital VACA, VAHU, and STVA components to the firm value.

This test is done using significance level 0.05 $(\alpha=5$ percent). Acceptance or rejection on the partial test is done when $t$ arithmetic $>t$ table or probability < level of significance ( $\mathrm{Sig}<0.05)$, then $\mathrm{H}_{0}$ is rejected, and $\mathrm{H}_{\mathrm{a}}$ accepted means independent variables affect the dependent variable. If $\mathrm{t}$ arithmetic < $\mathrm{t}$ table or probability $>$ level of significance (Sig > $0.05)$, then $\mathrm{H}_{0}$ accepted and $\mathrm{H}_{\mathrm{a}}$ rejected means the independent variable does not affect the dependent variable.

Table 7. Partial Test Results Test (t-test)

\begin{tabular}{lccc}
\hline $\begin{array}{c}\text { Variable } \\
\text { Independent }\end{array}$ & t Value & t Table & Significance \\
\hline VACA & 8.556 & 1.980 & 0.000 \\
VAHU & -5.658 & 1.980 & 0.000 \\
STVA & 0.690 & 1.980 & 0.802 \\
\hline
\end{tabular}

\section{DISCUSSIONS}

\section{The Effect of Value Added Capital Employed to The firm value}

Based on the results in the table above can be seen that for the variable VACA, $\mathrm{H}_{0}$ rejected and $\mathrm{H}_{\mathrm{a}}$ accepted because the level of significance of VACA of $0.000<0.05$. Thus it can be concluded that the variable VACA effect on PBV.

This is not in line with the results of the study Dewi \& Isynuwardhana (2014) and Sayyidah \& Saifi (2017), because there are differences in objects, as 
well as the study period. However, the results of this study are in line with the results of the study Werastuti (2014) and Wahyuni, Suratno, \& Anwar (2017) which states that VACA has a positive and significant effect on ROA and PBV. Physical capital or financial capital, i.e., all tangible capital such as cash, marketable securities, receivable accounts, inventories, land, buildings, machinery, equipment, furniture, fixtures, and vehicles owned by and then used in production and make efficiency in the process of creating corporate value. This means that information about the efficient use of capital employed is captured by the market (investor) so that it affects the firm value. Physical capital is managed efficiently and can generate added value for the company to generate the market firm value. This is because in appreciating the market value investors consider the influence of intellectual property (physical capital) owned by the company.

\section{The Influence of Value Added Human Capital To The firm value}

Based on the results in Table 7 above can also be seen that the decision of VAHU variable is $\mathrm{H}_{0}$ rejected and $\mathrm{H}_{\mathrm{a}}$ accepted because of the level of significance of VAHU of $0.000<0.05$. Thus it can be concluded that the variable VAHU affect the firm value PBV.

This is not in line with the results of research Li, Yang, \& Zhao (2018). However, the results of this study are in line with previous research conducted by (Nurani, Zulbahridar, \& Azhari, 2014; Wahyuni, Suratno, Anwar, 2017) which mentions the results of his research that VAHU affect the firm value MBV. The results of Sayyidah \& Saifi (2017) also concluded that VAHU variables significantly influence partially on the value of companies proxied by Tobins'Q.

This shows that investors give more value to companies that have greater VAHU. VAHU describes the amount of value added that can be gen- erated with funds spent on personal expenses (total salaries and wages). Companies that have the best employees with a ratio perpendicular to the costs incurred by the company get a lot of value added to them. It also shows that companies registered on LQ-45 already use human capital and utilize the knowledge their employees have to generate wealth for the company. With creativity and intelligence, employees can do the job in the best way that makes the company different from other companies. With the expertise, knowledge, and network of employees, the company can create the best solution that will increase market appreciation.

So this can benefit stakeholders because management can manage the organization for their interests. To complete companies must have a superior resource that can create value added for the company, in this case, human capital. Also, companies must be able to manage these resources to achieve competitive advantage. Competitive advantage is the capital in the face of business competition. So companies that have a competitive advantage can survive in the business environment.

\section{The Effect of Structural Capital Value Added to The firm value}

While for STVA variable because it has significant value above 0.05 then $\mathrm{H}_{0}$ is accepted, and $\mathrm{H}_{\mathrm{a}}$ is rejected because the level of significance of STVA is $0.492>0.05$. It can be concluded that STVA variable does not affect firm value PBV.

This is not in line with the results of research Simamarta \& Subowo (2016). However, the results of this study are in line with (Fajriani, 2017; Sayyidah \& Saifi, 2017; Wahyuni, Suratno, \& Anwar, 2017) also concluded that the VAHU variable significantly influences partially to the firm value produced by Tobins'Q. According to Chen, Cheng, \& Hwang (2005) states that STVA is not an appropriate measure because it only reflects the value added of structural capital. The disclosure of R \& D programs are 


\section{The Intellectual Capital Components on Firm Value: Evidence from LQ-45 Index Companies \\ Eristy Minda Utami}

that can improve the quality of production. If structural capital management is irregular and unfavorable, it will hinder the productivity of employees in generating value added and not able to increase the firm value.

In this study shows that the company's operational systems, organizational culture, management philosophy and all forms of intellectual property owned by the company are inefficient and economical in creating added value for the company. The company's existing Structural Capital is just the routine of all the individuals in the company, so it can not affect the production process and the creation of innovations for more innovative products that can increase the firm value.

\section{CONCLUSION AND SUGGESTIONS}

\section{Conclusion}

Based on the results of data and discussion that has been done, the researchers take the following conclusions: (1) VACA affects the firm value. This means that information about the efficient use of capital employed is captured by the market (investor) so that it affects the firm value. Physical capital is managed efficiently and can generate added value for the company to generate the market firm value; (2) VAHU affects the firm value. Companies that have the best employees with a ratio perpendicular to the costs incurred by the company get a lot of value added to them. With the expertise, knowledge, and network of employees, the company can create the best solution that will increase market appreciation; and (3) STVA has no effect on firm value. This shows that the existing company's structural capital is just the routine done by all the individuals in the company, so it can not affect the production process and the creation of innovations for more innovative products that can increase the firm value.

\section{Suggestions}

This study still has many limitations; therefore there are some suggestions. It is best to extend the study period, also by selecting larger sectors or other larger sectors because with larger sector selections expected to get much more accurate results, further research using firm value as a dependent variable should add financial performance to be able to see the direct and indirect relationship between intellectual capital to the firm value, it can also compare the application of intellectual capital to some other variables such as earning per share or financial performance, either inside or overseas.

\section{REFERENCES}

Chen, M. C., Cheng, S. J., \& Hwang, Y. (2005). An empirical investigation of the relationship between intellectual capital and firm's market value and financial performance. Journal of Intellectual Capital, 6(2), 159-176.

Dewi, I. R., Handayani, S. R., \& Nuzula, N. F. (2014). Pengaruh struktur modal terhadap nilai perusahaan. Jurnal Administrasi Bisnis, 17(1), 1-9.
Dewi, N. A. C., \& Isynuwardhana, D. (2014). Intellectual capital terhadap nilai perusahaan dengan kinerja keuangan sebagai variabel intervening. Jurnal Keuangan dan Perbankan, 18(2), 233-248.

Entika, N. L. (2012). Pengaruh elemen pembentuk intellectual capital terhadap nilai pasar dan kinerja keuangan pada perusahaan perbankan yang terdaftar di Bursa Efek Indonesia (BEI). Diponegoro Journal of Accounting, 1(2).
Fajarini, I. S. W., \& Firmansyah, R. (2012). Pengaruh intellectual capital terhadap kinerja keuangan perusahaan (Studi empiris perusahaan LQ45 yang tercatat di Bursa Efek Indonesia tahun 2005-2007). Jurnal Dinamika Akuntansi, 4(1), 1-12.

Fajriani, P. D. (2017). Pengaruh intellectual capital terhadap nilai perusahaan. Skripsi. Program Studi Manajemen Universitas Widyatama Bandung. 
Gujarati, D. N., \& Porter, D. C. (2009). Basic Econometrics. $5^{\text {th }}$ Edition. New York: McGraw Hill.

Ghozali, I. (2013). Aplikasi Analisis Multivariate dengan Program IBM SPSS. Edisi Kelima. Semarang: Badan Penerbit Universitas Dipenogoro.

Hamidah, H., Ahmad, G. N., \& Aulia, R. (2015). Effect of intellectual capital, capital structure, and managerial ownership towards firm value of manufacturing sector companies listed in IDX period 2010-2014. Journal Riset Manajemen Sains Indonesia, 6(2), 558-578.

Hermuningsih, S. (2012). Pengaruh profitabilitas dan size terhadap nilai perusahaan dengan struktur modal sebagai variabel intervening. Jurnal Siasat Bisnis, 16(2), 232-242.

Li, Y., \& Zhao, Z. (2018). The dynamic impact of intellectual capital on firm value: Evidence from China. Applied Economic Letters, 25(1), 19-23 https://doi.org/ $10.1080 / 13504851.2017$. 1290769 .

Lin, D. J., Yu, W., Wu, C., \& Cheng, T. (2018). Correlation between intellectual capital and business performance of construction industry - An empirical study in Taiwan. International Journal of Construction Management, 18(3), 232-246. https://doi.org/ 10.1080/15623599.2017.1315528.

Maditinos, D., Chatzoudes, D., Tsairidis, C., \& Theriou, G. (2012). The impact of intellectual capital on firms' market value and financial performance. Journal of Intellectual Capital, 12(1), 132-151.

Nurani, N. C., Zulbahridar, \& Azhari. (2014). Pengaruh intellectual capital terhadap nilai pasar perusahaan otomotif yang terdaftar di BEI 2007-2011. JOM FEKON, 1(2), 1-15.

Nuryaman \& Christina, V. (2015). Metodologi Penelitian Akuntansi dan Bisnis Teori dan Praktek. Bogor: Ghalia Indonesia.

Nopiyanti, I. D. A., \& Darmayanti, N. P. A. (2016). Pengaruh PER, ukuran perusahaan, dan profitabilitas pada nilai perusahaan dengan struktur modal sebagai variabel moderasi. Jurnal Manajemen Unud, 5(12), 7868-7898.

Pratama, I. G. B. A., \& Wiksuana, I. G. B. (2016). Pengaruh ukuran perusahaan dan leverage terhadap nilai perusahaan dengan profitabilitas sebagai variabel moderasi. E-Jurnal Manajemen Unud, 5(12), 13381367.

Riduwan. (2012). Dasar-dasar Statistika. Bandung: Alfabeta

Sayyidah, U., \& Saifi, M. (2017). Intellectual capital terhadap nilai perusahaan dengan profitabilitas sebagai variabel moderasi. Jurnal Administrasi Bisnis, 46(1), 163-171.

Simamarta, R., \& Subowo. (2016). Pengaruh intellectual capital terhadap kinerja keuangan dan nilai perusahaan perbankan Indonesia. Accounting Analysis Journal, 5(1), 1-9.
Suhardjanto, \& Wardhani. (2010). Praktik intellectual capital disclosure perusahaan yang terdaftar di Bursa Efek Indonesia. Jurnal Akuntansi dan Auditing Indonesia, 14(1), 59-66.

Sumedrea, S. (2013). Intellectual capital and firm performance: A dynamic relationship in crisis time. Procedia Economic and Finance, 6, 137-144.

Susanti. 2016. Pengaruh intellectual capital terhadap nilai perusahaan perbankan di BEI periode 2013-2015. Jurnal Bisnis Darmajaya, 2(2), 146-159.

Ulum, I. (2013). Model pengukuran kinerja intellectual capital dengan IB-VAIC di perbankan syariah. Jurnal Penelitian Sosial Keagamaan, 7(1), 185-206

Wahyuni, W., Suratno, \& Anwar, C. (2017). Pengaruh intellectual capital terhadap nilai perusahaan dengan free cash flow sebagai variabel moderating (Studi empiris pada perusahaan manufaktur secondary sectors di Bursa Efek Indonesia). Jurnal Ilmiah Ilmu Ekonomi, 6(11), 61-73.

Werastuti, D. N. S. (2014). Model mediasi dalam hubungan antara intellectual capital disclosure, nilai perusahaan, dan financial performance. Jurnal Keuangan dan Perbankan, 18(1), 14-28.

Yunita, N. (2012). Pengaruh modal intelektual terhadap kinerja keuangan dan nilai pasar. Accounting Analysis Journal, 1(1), 17. 